\title{
Archaeological Investigation of an Oil Well Pad Disturbance at the Tom Moore Site (41PN149), Panola County, Texas
}

Patti Haskins

Unknown

Mark Walters

Heritage Research Center, Stephen F. Austin State University

S. Elieen Goldborer

Follow this and additional works at: https://scholarworks.sfasu.edu/ita

Part of the American Material Culture Commons, Archaeological Anthropology Commons, Environmental Studies Commons, Other American Studies Commons, Other Arts and Humanities Commons, Other History of Art, Architecture, and Archaeology Commons, and the United States History Commons

Tell us how this article helped you.

This Article is brought to you for free and open access by the Center for Regional Heritage Research at SFA ScholarWorks. It has been accepted for inclusion in Index of Texas Archaeology: Open Access Gray Literature from the Lone Star State by an authorized editor of SFA ScholarWorks. For more information, please contact cdsscholarworks@sfasu.edu. 


\section{Archaeological Investigation of an Oil Well Pad Disturbance at the Tom Moore Site (41PN149), Panola County, Texas}

\section{Creative Commons License}

\section{(c) (1) \&}

This work is licensed under a Creative Commons Attribution-NonCommercial 4.0 International License 


\title{
ARCHAEOLOGICAL INVESTIGATIONS OF AN OIL WELL PAD DISTURBANCE AT THE TOM MOORE SITE (41PN149), PANOLA COUNTY, TEXAS
}

\author{
Patti Haskins and Mark Walters, with a contribution by S. Eileen \\ Goldborer
}

\section{INTRODUCTION}

The Tom Moore site (41PN149) is situated on the east slope of a circular-shaped landform at the highest point of a steeply-sloping upland in the Irons Bayou valley in Panola County, Texas. Irons Bayou, $1.2 \mathrm{~km}$ to the west of the site, flows east to its confluence with the Sabine River. A small tributary of Irons Bayou is $600 \mathrm{~m}$ to the south. Soils here are a brown sandy loam overlying a very hard red clay B-horizon. Like most of East Texas, the land has been farmed previously, as indicated by old plow furrows, and it has reforested naturally in pine and mixed hardwoods in the last 30 years. The site's upland setting is similar to other Middle Caddoan sites in the Sabine River basin in East Texas.

An oil field employee, J. W. Golden of Kilgore, Texas, located the Tom Moore site. He noticed a cache of seven large celts that had been disturbed by construction equipment preparing a well site. The oil well construction consisted of two wells and three associated storage tanks. Approximately 2 acres had been disturbed during the leveling process, and part of the hill was used to form the level well pad. A cultural resources management survey had not been required by the Railroad Commission of Texas prior to construction.

Mr. Golden described the celts as occurring in a group with the blade ends up. The heavy equipment had grazed them and caused some damage. He collected the celts and informed the authors. We visited the site, made a surface collection, noted a midden area at one end of the disturbance, and collected soil samples for flotation (these materials were submitted to S. Eileen Goldborer of Paleoethnobotanical Services, Austin, Texas) as well as OCR dates. No testing was conducted by the authors to determine the extent of the site. A small, circular mound is located in the wooded area adjacent to the well pad (Figure 1).

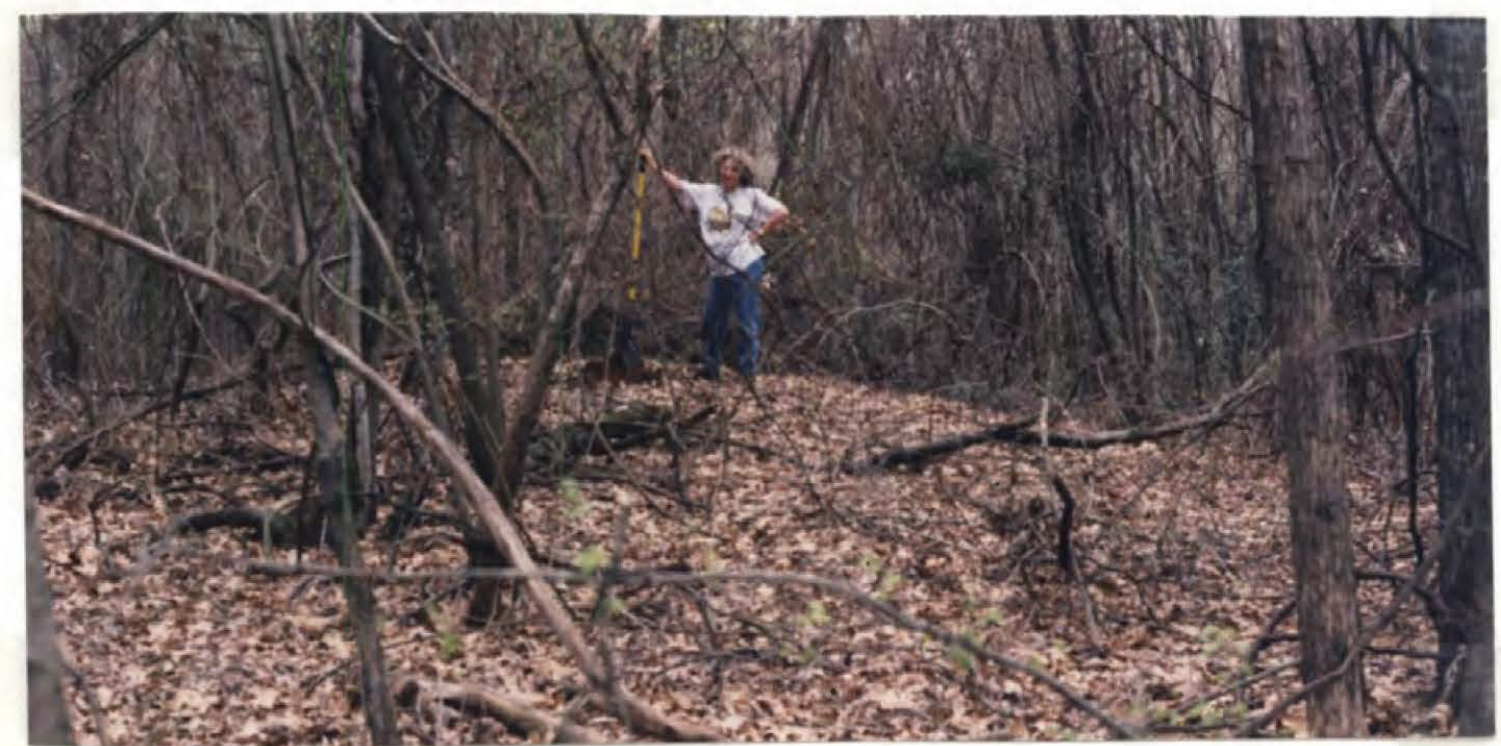

Figure 1. Mound at the Tom Moore site (41PN149). 


\section{MACROBOTANICAL ANALYSIS OF TWO FLOTATION SAMPLES FROM THE TOM MOORE SITE (41PN149), PANOLA COUNTY, TEXAS,}

\section{by S. Eileen Goldborer}

Two soil samples were collected from an exposed midden at the Tom Moore site (4IPN149) in 1997 by Mark Walters and Patti Haskins. The samples were floated and divided into light and heavy fractions before submission for macrobotanical analysis.

All charred and uncharred materials were sorted from the floated soil matrix, and the contents of the samples are summarized in Table 1. The primary carbonized plant material recovered was maize (Zea mays ssp. mays). However, some nutshell and charcoal, as well as a minute amount of cane (Arundinaria gigantea), were also retrieved. No charred seeds were present in the samples, although there was one uncharred grass (Gramineae) seed.

Table 1. Contents of Two Flotation Samples from the Tom Moore Site (41PN149).

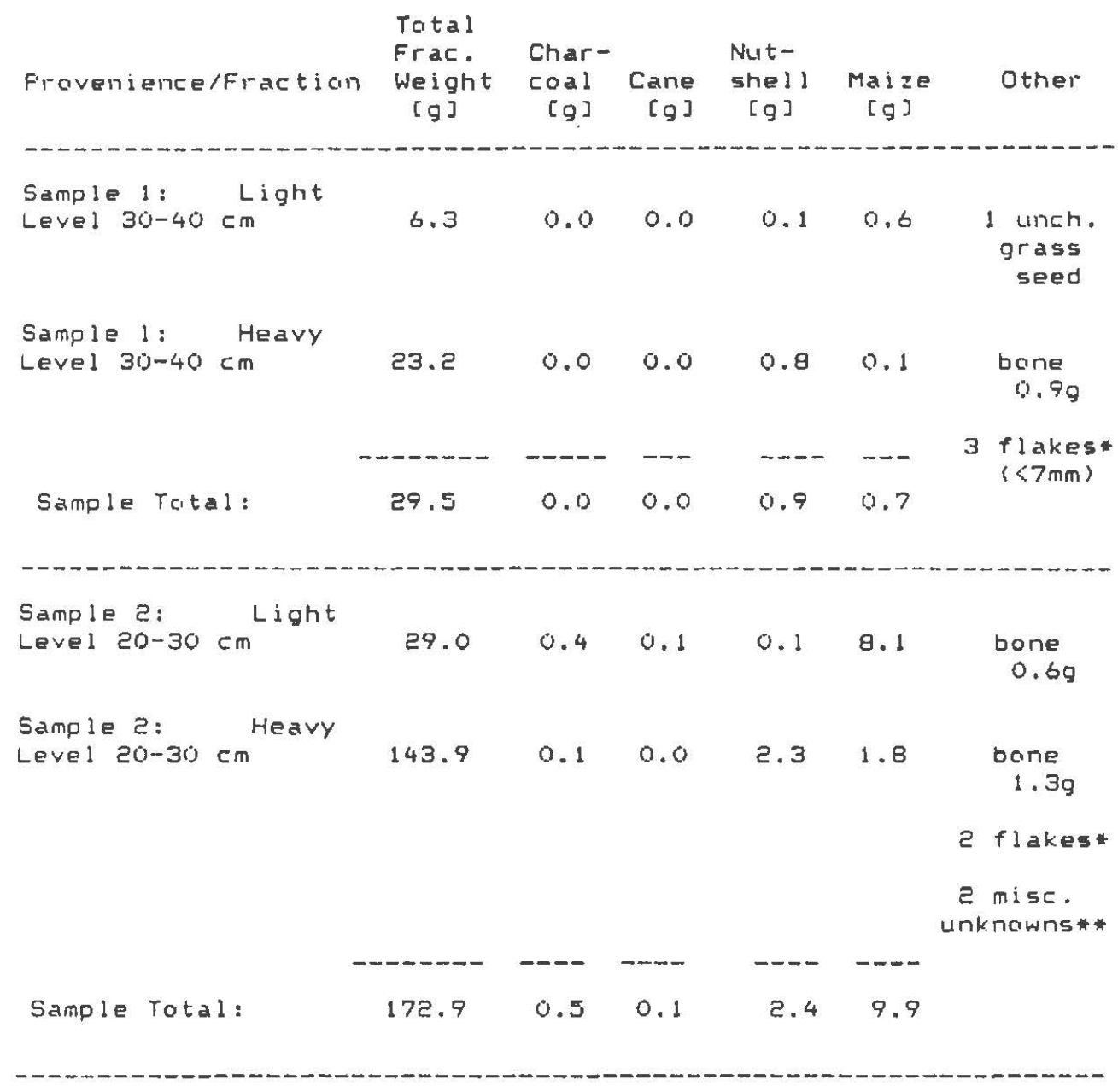

\footnotetext{
* =micro-flakes under $7 \mathrm{~mm}$, but appear to have identifiable flake chat acteristics

* * similar unkinciwns $(2-3 \mathrm{~mm})$. could be animal tocth crowns ai maybe fossilized unkinowins.
} 


\section{Methodology}

Individual light and heavy fractions for each sample were weighed, and passed through geological sieves $(4.0 \mathrm{~mm}, 2.0 \mathrm{~mm}, 1.0 \mathrm{~mm}$, and $0.5 \mathrm{~mm})$ to facilitate sorting. Charcoal and nutshell below $1.0 \mathrm{~mm}$ in size were not removed. Regardless of size, all other materials were removed from the soil matrix.

All fractions were sorted under a binocular microscope (7-45X). A comparative collection and standard identification manuals (Delorit 1970; Martin and Barkley 1973; Montgomery 1977) were used to identify seeds. As the small amount of charcoal was too fragile, no attempt was made to identify wood sources.

\section{Results}

\section{Charcoal, Nutshell, and Cane}

Only traces of charcoal and nutshell were present in the two samples. The nutshell was thick hickory. A minute piece of charred cane was preserved in Sample 2.

\section{Seeds}

No charred seeds were contained in the samples. One uncharred grass seed was recovercd from the fractions.

\section{Maize}

Charred maize was the primary botanical clement present in the samples. It represented $43.7 \%$ and $76.7 \%$ of all plant materials present in Sample I and 2, respectively. Table 2 summarizes their corn content. Individual cupule measurements and means are presented in Table 3 . Virtually all corn material was encrusted with a hardened, reddish-yellow soil matrix. That coating had to be carefully removed before any measurements could be made. Measurements were made with a caliper.

There was one crescent-shaped kernel with the embryo missing. Dimensions for the remaining portion of the charred kemel are $1.8 \mathrm{~mm}$ in width $\mathrm{x} 0.7 \mathrm{~mm}$ in thickness (internode length) $\times 1.3 \mathrm{~mm}$ in height (depth).

One cob mid-section of 12-rowed corn was present in Samplc 2. The cob section is very small, being only $15.4 \mathrm{~mm}$ in length. Its section diameter ranges from 7.1-7.5 mm, about the same as a pencil. The weight is $0.4 \mathrm{~g}$. The 20 whole cupules remaining on the cob section ranged from 1.7-4.4 mm in width, with a mean of $3.34 \mathrm{~mm}$. For the 12 measurable cupules, the mean internode length (approximate kernel thickness) was 1.46 $\mathrm{mm}$, but with a range from $0.9-2.0 \mathrm{~mm}$.

In addition to the cob section, 16 sets of two or more attached whole cupules were identified in the flotation samples. Two additional sets had one whole cupule with a partial cupule attached. All of these multi-cupule sets came from Sample 2. Sample 1 did not have any multi-cupule sets. Thirteen of the sets had two whole cupules attached axially; one had three; and another had four. Finally, one set had three whole cupules with a partial one attached axially. they were radially contiguous to three other whole cupules, which were also connected axially. 
Table 2. Maize Content Summary of Two Flotation Samples from Tom Moore (41 PN 149).

$\begin{array}{ccl}\text { Total } & & \text { Whale } \\ \text { Maize } & & \text { Single } \\ \text { Weight } & \text { Kernels } & \text { Cupules } \\ \text { (g) } & \text { (\#) } & (\#)\end{array}$

Sample/Level:

\section{Sample \#1}

$(30-40 \mathrm{~cm})$

0.7

0

Sample \#2

$(20-30 \mathrm{~cm})$

Site

Total:

9.9

10.6

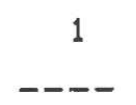

1
33

359

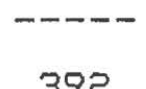

392

\author{
Multi- \\ Cupule \\ Sets \\ (\#)
}

Cob

Sections

(\#)

0

18

18

18
0

1
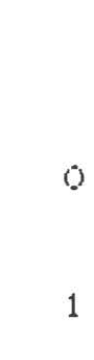

1

\section{Cupule Fragments} With Glumes (\#) Wi thout (\#)

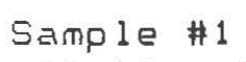

Tatal:

$$
10
$$

46

$----$

56

$$
41
$$

858

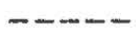

899
Unat tached Glumes

\#

4

$(30-40 \mathrm{~cm})$

Sample \#2

( $20-30 \mathrm{~cm}$ )

Site

Total:

54

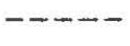

58
Glumes
Whole Single Cupules W. Glumes W/Q. Glumes (\#)
(\#)

\begin{tabular}{cc}
9 & 24 \\
98 & 261 \\
\hdashline 107 & - \\
\hdashline
\end{tabular}

Miscellameaus Cob
Fragments
$\#$
91

0

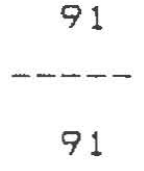


Table 3. Whole Maize Cupule Measurements and Means.

WHOLE CUFULES ON COE SECTION:

(Sample \#2)

Rank*/Cupule

1 a

1b

$1 c$

$1 d$

$1 \mathrm{e}$

$1 f$

$2 a$

2b

टc

2d

2e

एf

$3 a$

3b

$3 c$

3d

$3 e$

$3 f$

$4 a$

4b

$4 c$

$4 d$

$4 \mathrm{e}$

$4 f$

$5 a$

$5 b$

$5 c$

5d

Se

$5 f$

$6 a$

6b

bc

bd

be

$6 f$

Total Cupule Mean:

$\begin{array}{cc}\text { Cupule } & \text { Internode } \\ \text { Width } & \text { Length } \\ (\mathrm{mm}) & (\mathrm{mm})\end{array}$

$4.2 \quad 1.6$

$4.1 \quad 1.0$

$4.0 \quad 1.5$

$4.2 \quad 1.7$

4.21 .5

- -

$\begin{array}{cc}4.3 & 1.6 \\ 4.1 & - \\ 4.4 & 2.0 \\ - & - \\ - & -\end{array}$
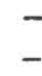

$\begin{array}{cc}- & - \\ 3.8 & 1.5 \\ - & -\end{array}$

4.2 1.7

3.3

3.3

2. 8

2.2

1.7

1.9

$-$

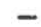

1.7

-

$\begin{array}{cc}2.9 & 1.1 \\ 2.8 & - \\ - & - \\ 2.8 & - \\ - & -\end{array}$

$-\frac{-1}{34}$

$1 . \overline{4}$ 
Table 3. Whole Maize Cupule Measurements and Means, cont.

MULTIFLE CUPULE SETS:

(Sample \#2*a)

\begin{tabular}{|c|c|c|}
\hline Set \#/Cupule & $\begin{array}{r}\text { Cupule } \\
\text { Width } \\
(\mathrm{mm})\end{array}$ & $\begin{array}{l}\text { Internode } \\
\text { Length } \\
(\mathrm{mm})\end{array}$ \\
\hline $1 \mathrm{a}$ & 4.4 & 3.2 \\
\hline $1 \mathrm{~b}$ & 2. $1+* b$ & 1.3 \\
\hline $2 a$ & 4.6 & 3.2 \\
\hline eb & 4.6 & 1.9 \\
\hline $3 a$ & 4.3 & 3.2 \\
\hline $3 b$ & $1 \cdot 1+* t$ & - \\
\hline $4 a$ & 4.6 & 2.9 \\
\hline $4 b$ & 4.6 & 1.2 \\
\hline $5 a$ & 4.3 & 2.3 \\
\hline 5b & 4.6 & 1.5 \\
\hline ba & 4.5 & 2.4 \\
\hline $6 b$ & 4.5 & - \\
\hline $7 a$ & 4.9 & 3.0 \\
\hline $7 b$ & $4.5+* 6$ & 2.9 \\
\hline $8 a$ & 4.1 & 2.2 \\
\hline $8 b$ & 4.1 & 0.8 \\
\hline $9 a$ & 4.4 & 1.4 \\
\hline 90 & 3.2 & 1.0 \\
\hline $10 a$ & 4.3 & 1.4 \\
\hline $10 b$ & 4.5 & 0.8 \\
\hline $11 \mathrm{a}$ & $3.6+* b$ & 2. 1 \\
\hline $11 \mathrm{~b}$ & 4.3 & 0.4 \\
\hline $12 a$ & 4.6 & 2.5 \\
\hline $12 b$ & 4.7 & 0.8 \\
\hline $13 a$ & 4.2 & 2.1 \\
\hline $13 b$ & 4.2 & 2.2 \\
\hline $14 a$ & 4.3 & 2.3 \\
\hline $14 b$ & $3.4+* b$ & 0.4 \\
\hline
\end{tabular}


Table 3. Whole Maize Cupule Measurements and Means, cont.

MULTIFLE CUFULE SETS(con't.):

(Sample \#2*a)

$\begin{array}{lcc}\text { Set \#/Cupule } & \begin{array}{r}\text { Cupule } \\ \text { Width } \\ \text { (mm) }\end{array} & \begin{array}{c}\text { Interncide } \\ \text { Length } \\ \text { (mm) }\end{array} \\ \text { 15a } & 4.8 & 2.2 \\ 15 b & 3.6 & 1.1 \\ 16 a & & \\ 16 b & 6.2 & 2.3 \\ 16 c & 6.3 & 3.0 \\ 17 a & 6.2 & 1.8 \\ 17 b & & \\ 17 c & 3.7 & 1.9 \\ 17 d & 4.1 & 2.2 \\ 170 & 4.5 & 2.2 \\ & 4.3 & 2.3\end{array}$

18(Fiank: 1)

$18 a$

$18 b$

$18 \mathrm{c}$

$18 d$

18 (Rank 2)

$18 \mathrm{e}$

$18 f$

$18 g$

4.6

2.4

5.1

4.7

2. 4

3.8+*b

2. 2

4.5

-

Total Cupule Mean:

4.6

2.6

2. 7

4.9

2. 3

$--\frac{-155^{-}}{4.5}$

$\overline{5} \cdot \overline{0}$

SINGLE WHOLE CUFULES:

$$
\text { Cupule No. }
$$

$$
\begin{aligned}
& \text { Cupule } \\
& \text { Width } \\
& \text { (mm) }
\end{aligned}
$$
Internode
Length
( $\mathrm{mm}$ )

Sample 1.:

1.
2.
3.
4.
5.
6.
7.
8.
9.
10.

6.8

3.4

3.6

5.8

4.5

5.0

5.1

4.3

6.6

2. 4

3.3

0.6

2. 4

1. 3

2. 6

1.3

$-$

1. 5

3.0

1.7 
Table 3. Whole Maize Cupule Measurements and Means, cont.

SINGLE WHOLE CUFULES (can't.):

$\begin{array}{ccc} & \text { Cupule } & \text { Internade } \\ \text { Cupule No. } & \text { Width } & \text { Length } \\ (\mathrm{mm}) & (\mathrm{mm})\end{array}$

Sample 1. (can't):

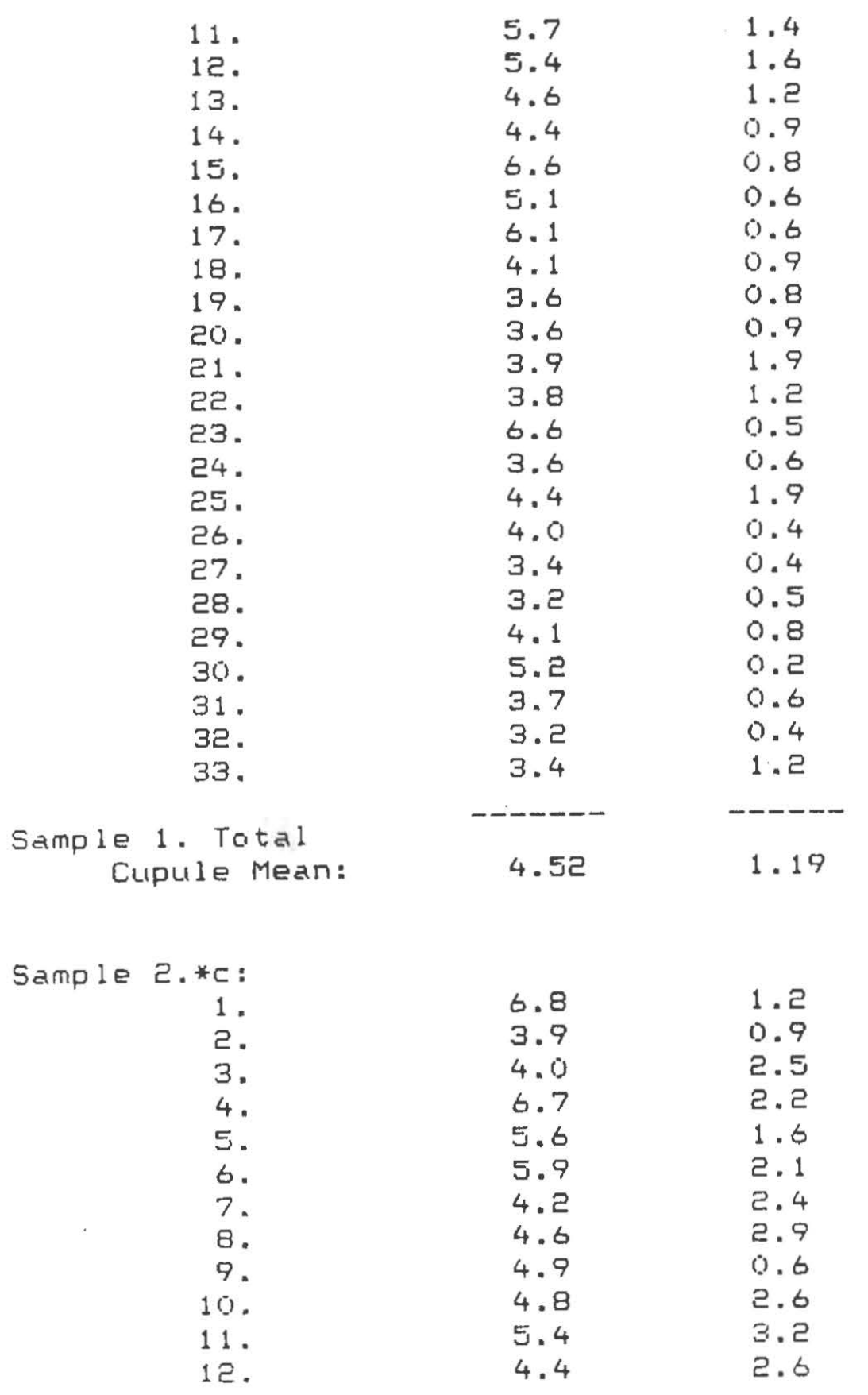


Table 3. Whole Maize Cupule Measurements and Means, cont.

SINGLE WHOLE CUPULES (can't.):

$\begin{array}{ccc} & \text { Cupule } & \text { Internade } \\ \text { Cupule } \mathrm{Na} . & \text { Width } & \text { Length } \\ & (\mathrm{mm}) & (\mathrm{mm})\end{array}$

Sample 2.*c (con't):

\begin{tabular}{|c|c|c|}
\hline 13. & 4.2 & 2.6 \\
\hline 14. & 3.4 & 2.4 \\
\hline 15. & 4.9 & - \\
\hline 16. & 4.3 & 0.9 \\
\hline 17. & 4.1 & 2. 1 \\
\hline 18. & 4.6 & - \\
\hline 19. & 4.5 & 2.9 \\
\hline 20. & 4.8 & 2. 7 \\
\hline 21. & 7.0 & 1.0 \\
\hline ટટ. & 6.9 & 0.6 \\
\hline 23. & 6.7 & 2. 4 \\
\hline 24. & 2.5 & 0.1 \\
\hline 25. & 2.8 & 0.7 \\
\hline 26. & 3.1 & 0.1 \\
\hline 27. & 3.1 & 0.4 \\
\hline 28. & 6.4 & 1.5 \\
\hline 29. & 6.3 & 3.1 \\
\hline 30. & 6.1 & 2.6 \\
\hline 31. & 4.5 & 1.2 \\
\hline 32. & 6.1 & 1.0 \\
\hline 33. & 5.8 & 3.1 \\
\hline 34. & 4.7 & 2.9 \\
\hline 35. & 5.7 & 1.7 \\
\hline 36. & 4.7 & 2. 1 \\
\hline 37. & 4.0 & 0.6 \\
\hline 38. & 4.8 & 1.8 \\
\hline 39. & 5.1 & 0.6 \\
\hline 40. & 4.5 & 0.9 \\
\hline 41. & 4.1 & 0.8 \\
\hline 42. & 5.0 & 0.5 \\
\hline 43. & 5.1 & 0.7 \\
\hline 44. & 4.7 & 1.0 \\
\hline 45. & 3.3 & 1.4 \\
\hline 46. & 5.1 & 1.3 \\
\hline 47. & 4.8 & 0.3 \\
\hline 48. & 3.6 & 1.0 \\
\hline 49. & 3.6 & 1.2 \\
\hline 50. & 3.4 & 0.5 \\
\hline 51. & 5.7 & 1.3 \\
\hline 52. & 4.2 & 0.7 \\
\hline 53. & 4.7 & 1.3 \\
\hline
\end{tabular}


Table 3. Whole Maize Cupule Measurements and Means, cont.

SINGLE WHOLE CUFULES (con't.):

$\begin{array}{ccc}\text { Cupule } & \text { Internode } \\ \text { Cupule } \mathrm{No} . & \text { Width } & \text { Length } \\ (\mathrm{mm}) & (\mathrm{mm})\end{array}$

Sample 2.*c ( $\left.\operatorname{con}^{\prime} t\right)$ :

$\begin{array}{lll}54 . & 5.2 & 0.8 \\ 55 . & 3.7 & 0.8 \\ 56 . & 3.9 & 0.4 \\ 57 . & 5.6 & 1.4 \\ 58 . & 4.2 & 0.8 \\ 59 . & 4.1 & 1.2 \\ 60 . & 4.5 & 1.2 \\ 61 . & 4.8 & 1.7 \\ 62 . & 4.2 & 1.1 \\ 63 . & 4.2 & - \\ 64 . & 4.6 & 2.2 \\ 65 . & 4.0 & 2.5 \\ 66 . & 5.3 & 0.7 \\ 67 . & 5.4 & 1.6 \\ 68 . & 5.6 & 0.3 \\ 69 . & 3.4 & 2.4 \\ 70 . & 3.7 & 1.8 \\ 71 . & 3.7 & 1.8 \\ 72 . & 5.3 & 0.7 \\ 73 . & 4.6 & 1.5\end{array}$

Sample 2. Total

Cupule Mean:

$4.71 \quad 1.48$

Combined Samples 1 : 2

Single whole
Cupule Mean:
4.65
1.39

Combined Samples $1 \& 2$

All Whole Cupule Mean: $4.47 \quad 1.56$

* There are half as many ranks as rows. Twa kernels are assciciated with one cupule.

*aNo multi-cupule sets were present in Sample 1.

* bcupule widths that were nat camplete were recarded, but not coulinted to get means.

* In order to reduce pracessing time, only 20.3 percent of the 359 Sample 2 single whole cupules were measured. 
The 38 whole cupules attached to multi-cupule sets had widths ranging from 3.2$6.3 \mathrm{~mm}$. They had a mean width of $4.55 \mathrm{~mm}$. On three cupulcs, the internode length was not measurable, but for the remaining 41 , it ranged from $0.4-3.2 \mathrm{~mm}$. The mean was 2.02 $\mathrm{mm}$.

Threc-hundred and fifty-nine single whole cupules were also in Sample 2, along with 33 from Sample 1. Measurements were made on all single whole cupulcs in Sample 1. In order to reduce processing time for the large number of single whole cupules in Sample 2 , only $73(20.3 \%)$ were mcasured.

The single whole cupules from Sample 2 were passed through geological sieves with $4.0 \mathrm{~mm}, 2.0 \mathrm{~mm}, 1.0 \mathrm{~mm}$, and $0.5 \mathrm{~mm}$ openings. No cupules fell below the $2.0 \mathrm{~mm}$ level; therefore, an approximately equal number were drawn from levels above the $2.0 \mathrm{~mm}$ and $4.0 \mathrm{~mm}$ screens. The three largest and smallest cupules from each level werc deliberately chosen for inclusion in the measured group of single whole cupules from Sample 2. An attempt was also made to draw approximately half of those cupules from sub-groups that had whole or partial glumes attached and from those that did not.

A total of 106 single whole cupules from both samples were measured. The width range was $2.4 \mathrm{~mm}$ to $7.0 \mathrm{~mm}$. The width and internode length means for the combined samples were $4.65 \mathrm{~mm}$ and $1.39 \mathrm{~mm}$, respectively. The width mean was virtually the same as for whole cupules in multi-cupule sets, but larger than for those on the cob mid-section. Converscly, that internode length was approximately the same for whole cupules on the cob section, but smaller than for those in multi-cupule sets.

Additionally, 955 cupules and 91 cob fragments were gleaned from the samples. Fifty-eight unattached glumes were also removed from the two samples.

\section{Discussion}

The four types of plant remains represented in the two flotation samples from the Tom Moore site include wood charcoal, nutshell, cane, and maize. Wood charcoal and nutshell are commonly recovered from sites of all prehistoric periods in East Texas. Cane occurs in Caddoan sites, but its use may have an older origin. So far, maize has not been recovered in Fast Texas from sites dating earlier than the Caddoan era (ca. A.D. 800).

The flotation samples from Tom Moore yielded only $14.5 \mathrm{~g}$ of botanical materials. Eighty-four percent of all the plant remains was maize. The one tiny kerncl among the maize remains was crescent-shaped and was wider than thick. That shape is considered typical of Eastern Complex or eight-rowed corn (Cutler and Blake 1973). Only one cob section survived in the samples. It was 12-rowed. Eastern Complex corn can have 10 or 12 rows (Brown and Anderson 1947; Jones and Fonner 1954:107; Wagner 1986:115). The cupules preserved on the cob fragments were also wider than thick, indicating Eastern Complex corn. Cupules in four of the six "ranks" of that cob were of a size which could be associated with small kernels, the approximate width of the one recovered from Sample 2. Two spikelets, each bearing a kernel, are associated with one cupule, which approximates the width of the "rank."

All other measured whole cupules also had a width greater than the length, which is a characteristic of Fastern Complex corn. The width of cupules from the Tom Moore site did not exceed $7 \mathrm{~mm}$, which is below the maximum established for a small Eastern eightrowed com (Bird and Dobbs 1986:94). The width range $(1.7 \mathrm{~mm}$ to $7 \mathrm{~mm}$ ) and mean $(4.47 \mathrm{~mm})$, as well as the internode length range $(0.4-3.2 \mathrm{~mm})$ and mean $(1.56 \mathrm{~mm})$ for all 
measured whole cupules, from the Tom Moore samples are consistent with those from other Caddoan sites (Blake 1994; Early 1988:134; Fritz 1989:73-75, 1992:6-8; Goldborer 1988:18, 1995:6-9, 17-18, 1998; Goldborer and Perttula 1999).

The maize from the Tom Moore site therefore generally fits the criteria for a small Eastern Complex corn, as it the case at various other Caddoan sites. However, identification of maize type or types and origin of prehistoric Caddoan corn have not been resolved. Among Caddoan sites where cob row numbers have been determined and cupule or kemel size indicate the presence of Eastern Complex corn, 14-rowed cobs have sometimcs been present (Blake 1994; Farly 1988:134; Ford 1997:107). Blake (1994) identificd 16-rowed cobs from the Rowland Clark site (41RR77) in Red River County, Texas. Recently, Ford (1997:104-107) examined corn excavated from the George C. Davis site (41CE19), and there were a few 14-rowed cobs as well as 6-, 8-, 10-, and 12-rowed cobs. The maize was identified as predominantly Eastern Complex, but he allowed for the possibility that the 14-rowed corn could represent another type (Ford 1997:107).

The cob portion recovered at the Tom Moorc site was only a mid-section. This demonstrates one problem in identifying maize type in the Caddoan region. Cob shape and dimensions have usually not been attainable from Caddoan maize remains. Those characteristics are important in defining the maize type. The 156 cobs that Ford $(1997: 107)$ examined from the 1968-1970 George C. Davis site excavations have not been analyzed in this way, but a full report on that collection would offer an important data base about Caddoan maize.

It is impossible to evaluate the importance of maize at the Tom Moore site from only two samples recovered from one exposed midden. The total number of whole cupules identified in the samples probably represent less than the total on a few cobs. However, because the site may be at least sevcral acres in size, there may be more opportunity to retrieve maize and other plant foods if additional excavations are ever carried out there. In the meantime, the botanical remains from the Tom Moore site have contributed somc additional data to the increasing body of information on Caddoan subsistence.

\section{Summary}

Maize was the primary carbonized botanical material recovered from the two flotation samples at the Tom Moore site. The maize characteristics are consistent with those of a small Eastern Complex corn. While the amount of reliance on maize agriculture cannot currently be determined for the Tom Moore site, this information increases the regional paleoethnobotanical data base.

\section{ARTIFACTS FROM THE TOM MOORE SITE (41PN149)}

We collected 924 artifacts in an uncontrolled surface survey (Table 4), almost exclusively ceramic sherds $(95.5 \%)$, along with a few cores, tested cobbles, and lithic debris. The most distinctive lithic artifact is the seven groundstone celts found in a cache at the site. 
Table 4. Artifact Inventory from the Tom Moore Site (41 PN 149 ).

\begin{tabular}{|c|c|c|c|}
\hline C.AASS & Type & No. & Percent \\
\hline \multirow[t]{2}{*}{ CERAMICS } & $\begin{array}{l}\text { Plain Body } \\
\text { Decorated Body } \\
\text { Decorated Rim } \\
\text { Plain Rim } \\
\text { Daub/Fired Clay } \\
\text { Base Sherds } \\
\text { Pipe Fragments }\end{array}$ & $\begin{array}{l}558 \\
270 \\
30 \\
11 \\
7 \\
5 \\
2\end{array}$ & $\begin{array}{l}60.4 \\
29.2 \\
3.2 \\
1.2 \\
0.8 \\
0.5 \\
0.2\end{array}$ \\
\hline & subtotal & 883 & 95.5 \\
\hline \multirow[t]{3}{*}{ LITHICS } & $\begin{array}{l}\text { Tested Cobble } \\
\text { Primary Flakes } \\
\text { Secondary Flakes } \\
\text { Tested Petrified Wood } \\
\text { Core } \\
\text { Celts }\end{array}$ & $\begin{array}{l}12 \\
8 \\
5 \\
7 \\
2 \\
7\end{array}$ & $\begin{array}{l}1.3 \\
0.9 \\
0.5 \\
0.8 \\
0.2 \\
0.8\end{array}$ \\
\hline & subtotal & 41 & 4.5 \\
\hline & Total Artifacts & 924 & 100.0 \\
\hline
\end{tabular}

\section{Ceramics}

The ceramics are categorized in the sherd summary (Table 5), along with numbers and percentages of the decorated rim and body sherds (Table 6), analysis of the profile and lip of the rim sherds (Table 7), and Table 8 provides the temper analysis of the plain and decorated sherds. The sherd assemblage consisted of 41 rims (11 of which are plain), five bases, 270 decorated body sherds, and 558 plain body sherds. About $34 \%$ of the sherds are decorated, and the plain to decorated sherd ratio is 1.91. To glean as much information as possible from our artifacts, we studied each sherd to determine its composition and measured the wall thickness. Although not conclusive, our studies suggest that the vessels we thought were more utilitarian in function, had thicker walls and contained more bone temper.

Overall, approximately $53 \%$ of the sherds had only grog temper and about $24 \%$ contained bone (see Table 8 ), but always in combination with grog and/or grit temper. Almost 29\% of the sherds have grit inclusions. Taking as a given that temper is an agent intentionally added to the clay paste for a specific purpose, we included all sherds in the grog class that had visually identifiablc grog. Some sherds had a noticeable gritty feel and upon examination had inclusions that were larger than clay particles and these were listed in the grit class. Admittedly, this is a gray area, but our classes were based on both physical and visual (with the aid of a microscope) differences. Two engraved sherds of apparent local manufacture were selected for instrumental neutron activation analysis, and the results are reported in Perttula (2000a). 
Table 5. Sherd Summary, Tom Moore site (41PN149).

\begin{tabular}{llll}
\hline CLASS & TYPE & NO. & Percent \\
\hline CERAMICS & Decorated Body & 270 & 30.9 \\
& Decorated Rims & 30 & 3.4 \\
& Plain Rims & 11 & 1.3 \\
Bases & 5 & 0.6 \\
& Plain Body & 558 & 63.8 \\
& Total Sherds & 874 & 100 \\
\hline
\end{tabular}

The most common punctated design elements consisted of fingernail impressions, small reed-like circles, triangular marks, and large instrument gouges (Figure 2a). Incised designs were dominated by one or more straight lines (Figure 2b). There were 10 sherds with fine combed parallel lines similar to Pease Brushed-Incised. Other incised elements were opposing lines forming triangles and cross-hatching (see Figure 2b), resembling the decoration on Maydelle Incised vessels. One sherd was decorated with a circular incised line. An incised sherd with opposing lines had a white slip on both interior and exterior surfaces.

Of the punctated-incised sherds (see Table 6), 28 had parallel straight lines separating zones of punctates. Four had curvilinear lines enclosing zones of punctates. Appliqued sherds and vessels are uncommon in prehistoric Caddoan sites on the middle Red River (Perttula 2000b:Table 5). One punctated-incised rim had rows of reed punctates inside alternating rows of horizontal incised lines interrupted by a vertical appliqued ridge that extended $4 \mathrm{~cm}$ down from the lip (Figure 2c, center, top row). Two other appliqued sherds had a single appliqued ridge, and another had two circular bumps (Figure 2d, right). Alongside these uncommon decorative techniques, it is interesting to note the long life of variants of Crockett Curvilinear Incised and Pennington Punctated Incised (see Figure 2c, top row. Left, and bottom row, center and right).

About $20 \%$ of the decorated sherds had brushing alone with evidence of horizontal and vertical brushing (see Table 6). A heavy black residue was noted on the interior of one brushed sherd, and it likely derived from a cooking jar. There was one body sherd with a brushed-pinched-punctated decoration. Three rim sherds were decorated with rows of punctates around the rim with horizontal brushing similar to Pease Brushed-Incised (see Suhm and Jelks 1962). 


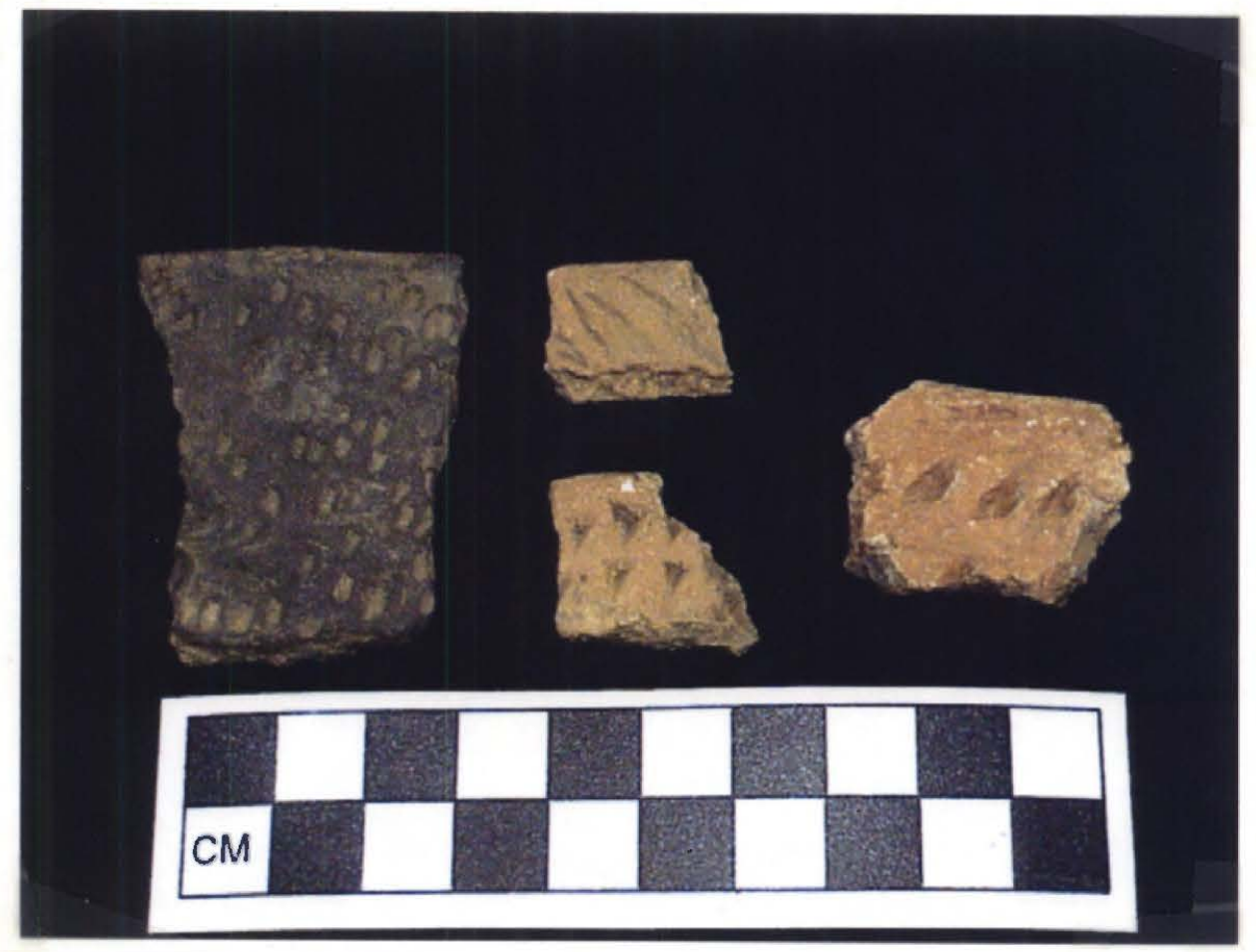

Figure 2a. Punctated sherds.

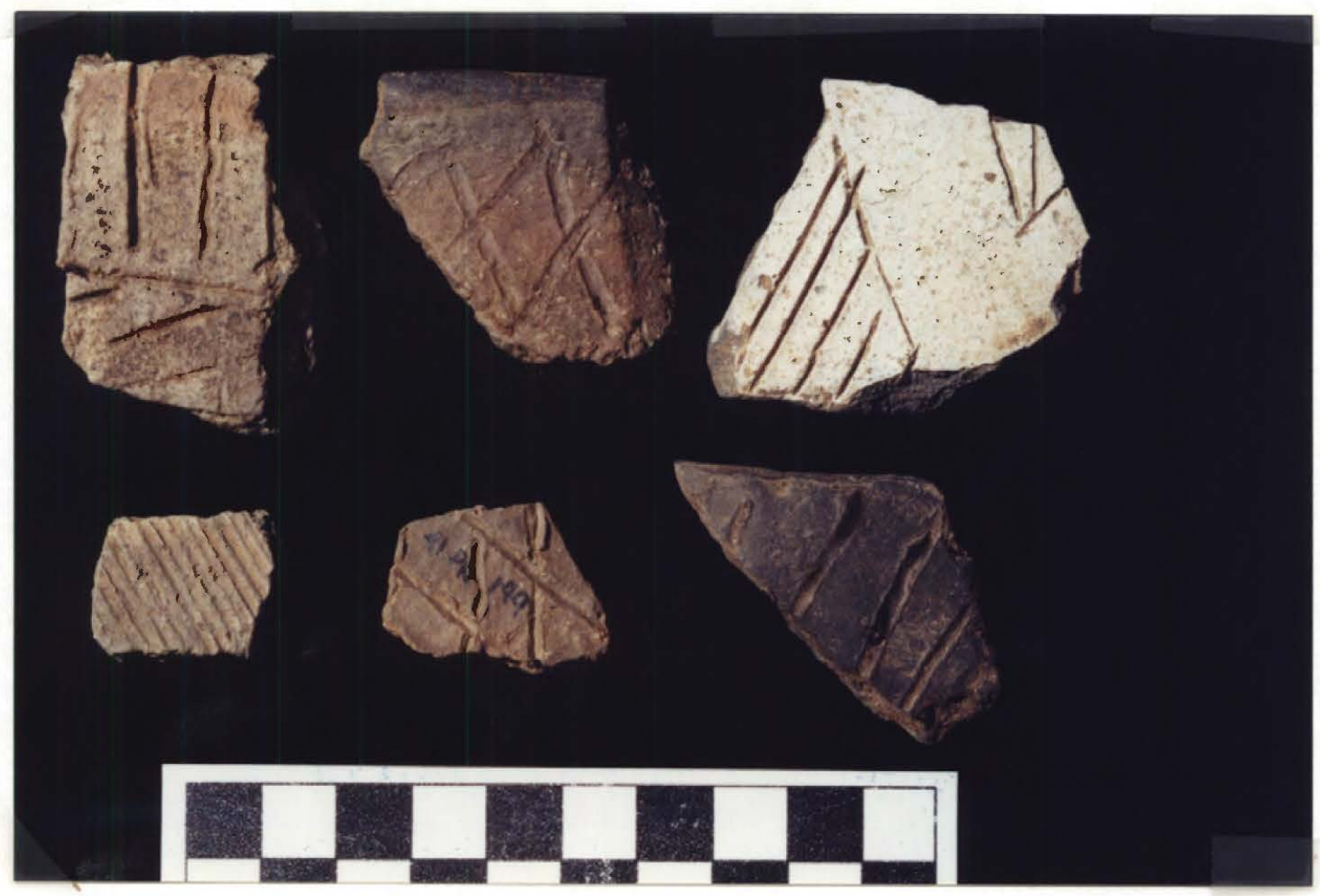

Figure $\mathbf{2 b}$. Incised sherds. 


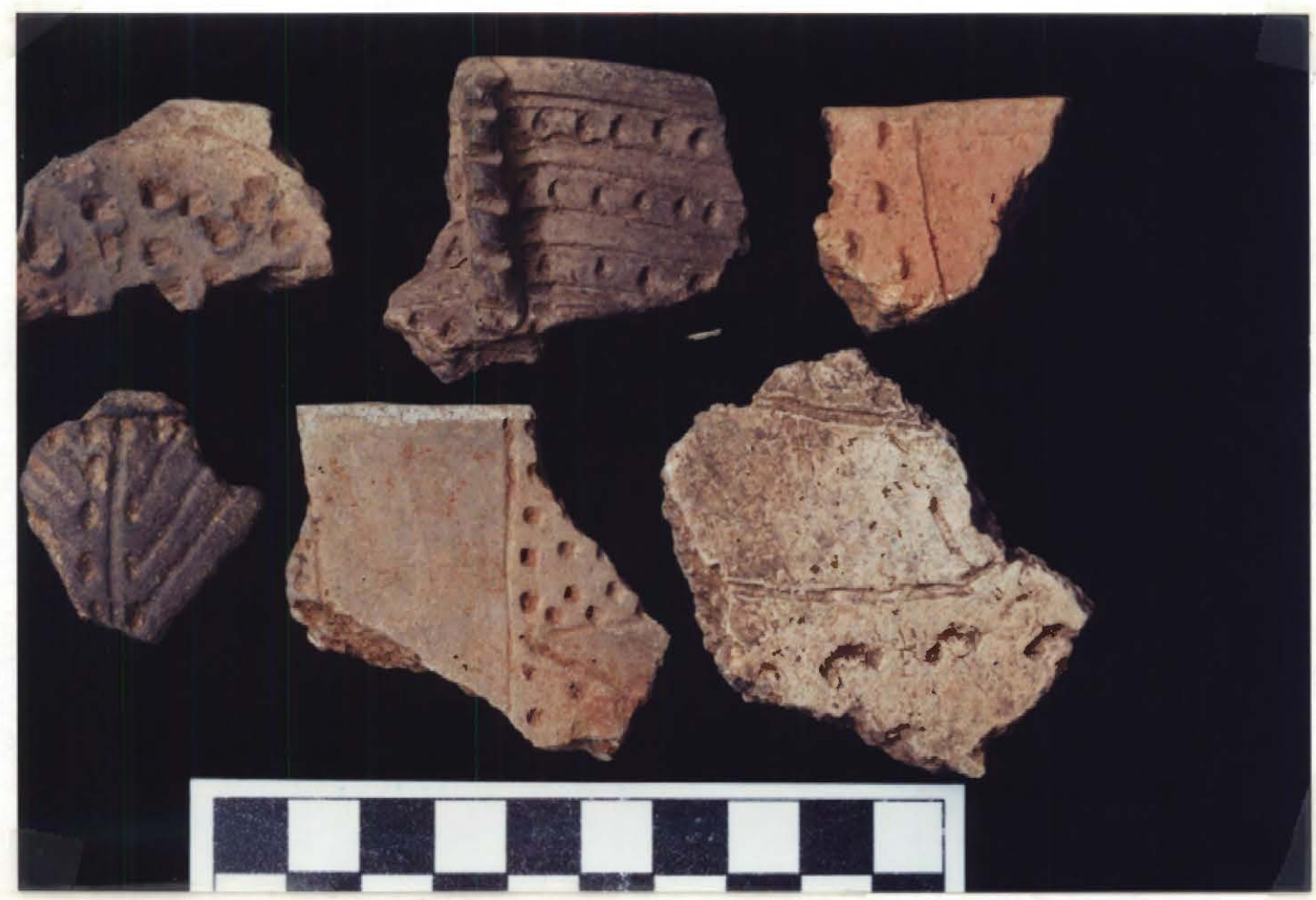

Figure 2c. Punctated-incised and punctated-incised-appliqued sherds.

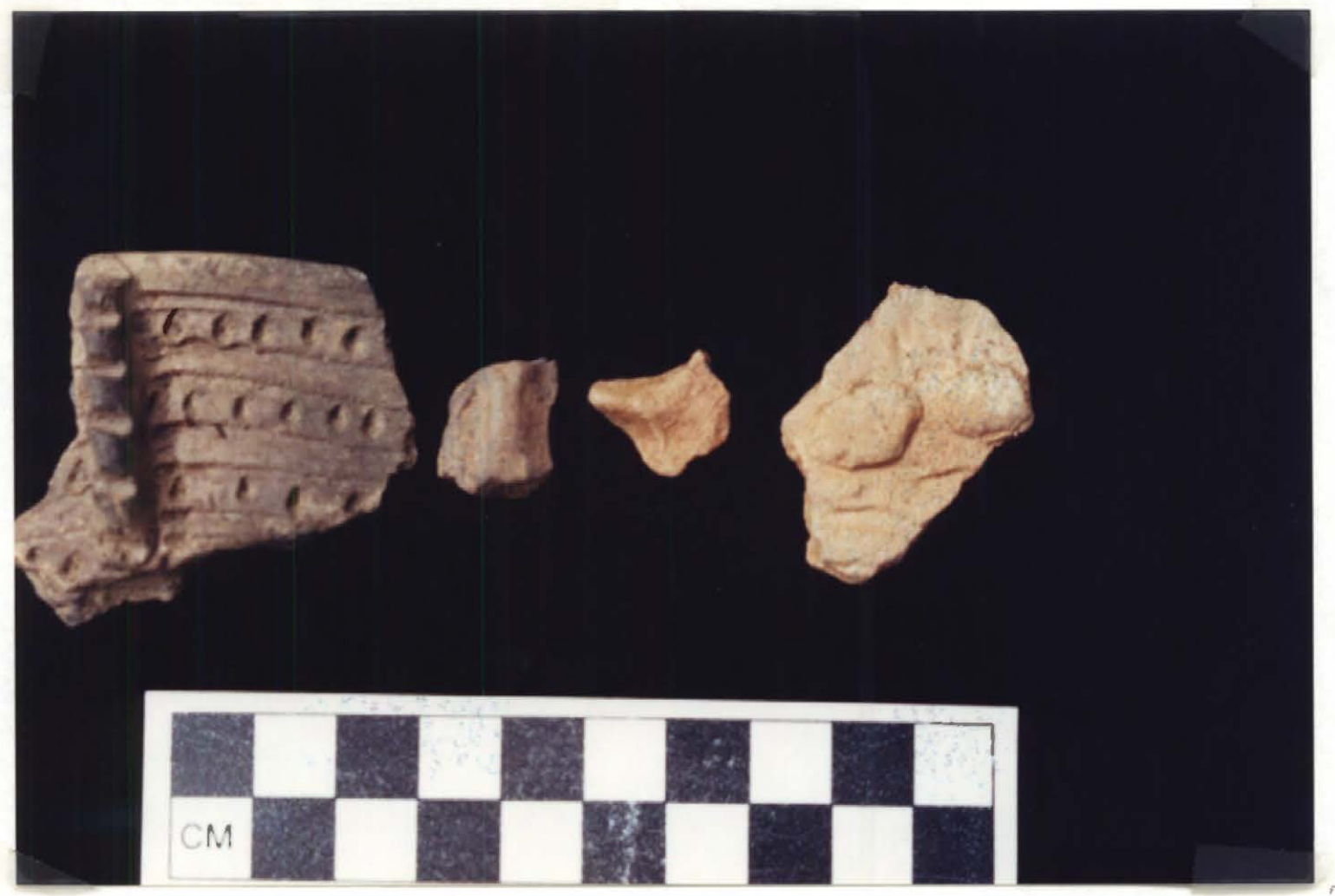

Figure 2d. Appliqued sherds. 
Table 6. Decorated Sherds, Tom Moore site (41PN149).

\begin{tabular}{llll}
\hline CLASS & TYPE & NO. & Percent \\
\hline BODY & Punctated & 85 & 31.5 \\
& Incised & 62 & 23.0 \\
& Brushed & 64 & 23.7 \\
& Punctated/Incised & 32 & 11.9 \\
& Engraved & 26 & 9.6 \\
& Brushed/pinched/punctated & 1 & 0.3 \\
& & & 100.0 \\
& Total & 270 & 22.0 \\
& Incised & 9 & 22.0 \\
& Punctated & 9 & 26.8 \\
& Plain & 11 & 7.3 \\
& Punctated/Incised & 3 & 9.8 \\
& Brushed/Punctated & 4 & 12.0 \\
& Engraved & 5 & 100.0 \\
\hline
\end{tabular}

Of the 26 engraved body sherds (Figure 3), four were decorated with opposing lines, five with cross-hatched filled panels, and one had an engraved line with pendant triangles on both sides. Another engraved sherd had been decorated with a cross-hatched circle within a larger circle with a star burst excised design. This sherd also had two very fine straight lines running through the design element. There were five engraved rim sherds. Three had one or more horizontal lines below the lip, another was a black, burnished sherd with a ladder-like design. The other rim, and five body sherds, had only a single engraved line from undetermined decorative elements.

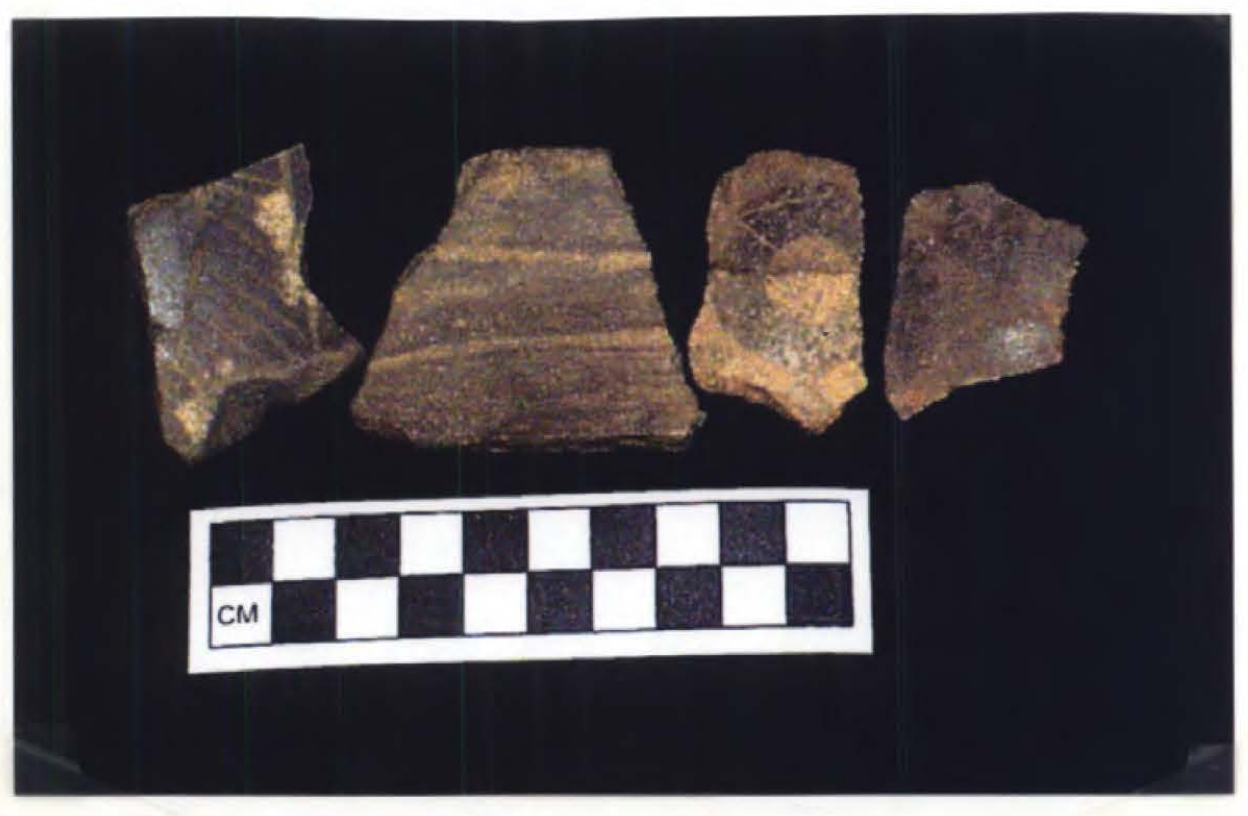

Figure 3. Engraved sherds from the Tom Moore site. 
Table 7. Rim Analysis.

\begin{tabular}{|c|c|c|c|c|c|c|}
\hline \multirow{2}{*}{ TYPE } & \multirow[t]{2}{*}{ NO. } & \multicolumn{2}{|c|}{ RIM PROFILE } & \multicolumn{3}{|c|}{ LIP FORM } \\
\hline & & STRAIGHT & EVERTED & FLAT & ROUND & ROLLED \\
\hline Engraved & 5 & 3 & 2 & 1 & 3 & 1 \\
\hline Brushed/Punctated & 4 & 3 & 1 & 2 & - & 2 \\
\hline Incised/Punctated & 6 & 1 & 5 & - & 6 & - \\
\hline Incised & 9 & 2 & 7 & 1 & 7 & 1 \\
\hline Punctated & 9 & 1 & 8 & 1 & 6 & 2 \\
\hline Plain & 11 & 7 & 4 & 1 & 10 & - \\
\hline Total & 44 & 17 & 27 & 6 & 32 & 6 \\
\hline Total Percentage & & $39 \%$ & $61 \%$ & $14 \%$ & $73 \%$ & $14 \%$ \\
\hline
\end{tabular}

Table 8. Temper Analysis, Tom Moore site (41PN149).

\begin{tabular}{|c|c|c|c|c|c|c|c|c|}
\hline Type & Grog & $\%$ & $\begin{array}{l}\text { Grog- } \\
\text { Bone }\end{array}$ & $\%$ & $\begin{array}{l}\text { Grog- } \\
\text { grit }\end{array}$ & $\%$ & $\begin{array}{l}\text { Grit- } \\
\text { bone-grog }\end{array}$ & $\%$ \\
\hline Plain body & $\overline{297}$ & $53 . \overline{2}$ & 102 & 18.3 & 128 & 23.0 & 31 & 5.5 \\
\hline Base & 3 & 60.0 & I & 20.0 & - & - & 1 & 20.0 \\
\hline \multicolumn{9}{|c|}{ Decorated Body } \\
\hline Incised & 42 & 68.0 & 18 & 29.0 & 2 & 3.0 & - & - \\
\hline \multicolumn{9}{|l|}{ Punctated- } \\
\hline Brushed & 33 & 51.6 & 5 & 7.8 & 21 & 32.8 & 5 & 7.8 \\
\hline Engraved & 15 & 57.7 & 6 & 23.1 & 5 & 19.2 & - & - \\
\hline \multicolumn{9}{|c|}{ Brushed-Pinched- } \\
\hline Punctated & - & - & 1 & 100.0 & - & - & - & - \\
\hline Punctated & 38 & 44.7 & 25 & 29.4 & 21 & 24.7 & 1 & 1.2 \\
\hline \multicolumn{9}{|l|}{ Rims } \\
\hline Plain & 7 & 63.6 & 3 & 27.3 & 1 & 9.1 & - & - \\
\hline Incised & 6 & 66.7 & 1 & 33.3 & - & - & - & - \\
\hline \multicolumn{9}{|l|}{ Punctated } \\
\hline Incised & 2 & 66.7 & 1 & 33.3 & - & - & - & - \\
\hline \multicolumn{9}{|l|}{ Brushed- } \\
\hline Punctated & 4 & 75.0 & 1 & 25.0 & - & - & - & - \\
\hline Engraved & 3 & 60.0 & 2 & 40.0 & - & - & - & - \\
\hline Punctated & 2 & 22.2 & 5 & 55.6 & 2 & 22.2 & - & - \\
\hline
\end{tabular}

Most of the rims have everted profiles (61\%), with rounded lips. In the decorated rims, straight rims are most common among the brushed-punctated vessels, and these also tend to have rolled lips. In the other decorated sherds, everted profiles dominate, along with rounded lips (see Table 7). 
There were also 11 plain rims, seven with straight profiles and four with everted profiles. All had round lips (sce Table 7). 'The five flat bases ranged from 5 to $15 \mathrm{~mm}$ in thickness. The $5 \mathrm{~mm}$ thick one had a red slip on both interior and exterior surfaces. The 328 plain body sherds were studied to determine temper and sherd thickness (see Table 8).

There were two pipe fragments, one round stem fragment and one portion of a bowl with a white slip. Seven irregular pieces of daub or fired clay were recovered from the soil sample. No impressions were evident; however, two pieces had bone inclusions.

\section{Lithics}

True to form on Middle Caddoan sites in the Middle Sabine Basin, the rarity of lithic artifacts (see Table 4) raises questions that need to be addressed in future studies. If these sites were occupied on a year-round basis, there should be evidence of on-site stone tool manufacture, resulting in a complete range of finished products to waste material. Such is not the case at the Tom Moore site, but the lithic sample is rather small. From the limited available evidence, the reduction process there utilized small local cobbles of red, tan, and grey quartzites as well as local petrified wood.

It is possible that the scarcity of lithic tools and debris at the Tom Moore site is a reflection that technology had changed and the use of stone had been replaced by organic substances, such as bone, antler, or cane. The changing of trade networks could have altered the flow of materials into this lithic-poor region, although the presence of the celts would indicate that trade was still open on some levels. Not enough information is currently available to determine whether or not there was change in subsistence patterns about the time the Tom Moore site was occupied, and whether the lack of lithic materials in the artifact assemblage is any indicator of such a change. Maize was recovered in some abundance (see Goldborer, this paper) but how reliant the population was on it or other domesticates. which were lacking from the floral sample, is at present unknown.

The most remarkable fact about the Tom Moore site is the presence of the seven large celts that prompted this study. Of the seven celts, only five were available for detailed study. They were analyzed by Mike Howard, Geology Supervisor/Mineralogist of the Arkansas Geological Commission. Four were identified as greywacky sandstone from the southern half of the Ouachita Mountains (Figures 4a-b and 5a-b). The spatulate celt (Figure 6) was identified as 'Titanite or Magnet Cove Jade, the nearest source being Cove Creek near Magnet Cove, Arkansas.

Titanite-Sphene-Magnet Cove Jade is a member of the Silicate family. In the United States, it occurs in igneous rocks in Maine, Massachusetts, New York, New Jersey, and Magnet Cove, Arkansas. Hardness is 5 to 5.5. The clear, green, yellow, or brownish varieties are used for gem purposes (Arkansas Geological Commission 1998). 

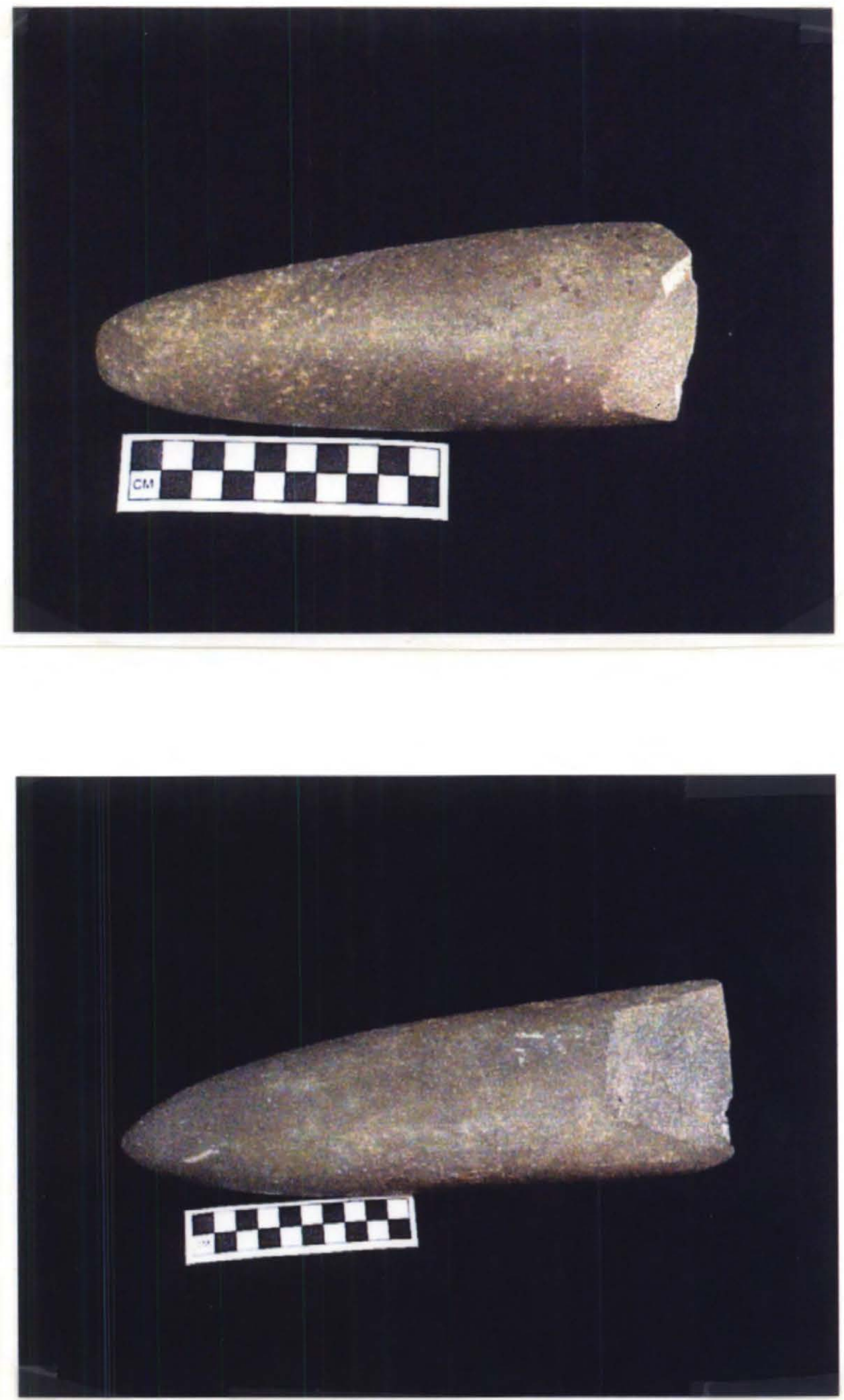

Figure 4. Celts from the Tom Moore site: $a$, top of page; $b$, bottom of page. 

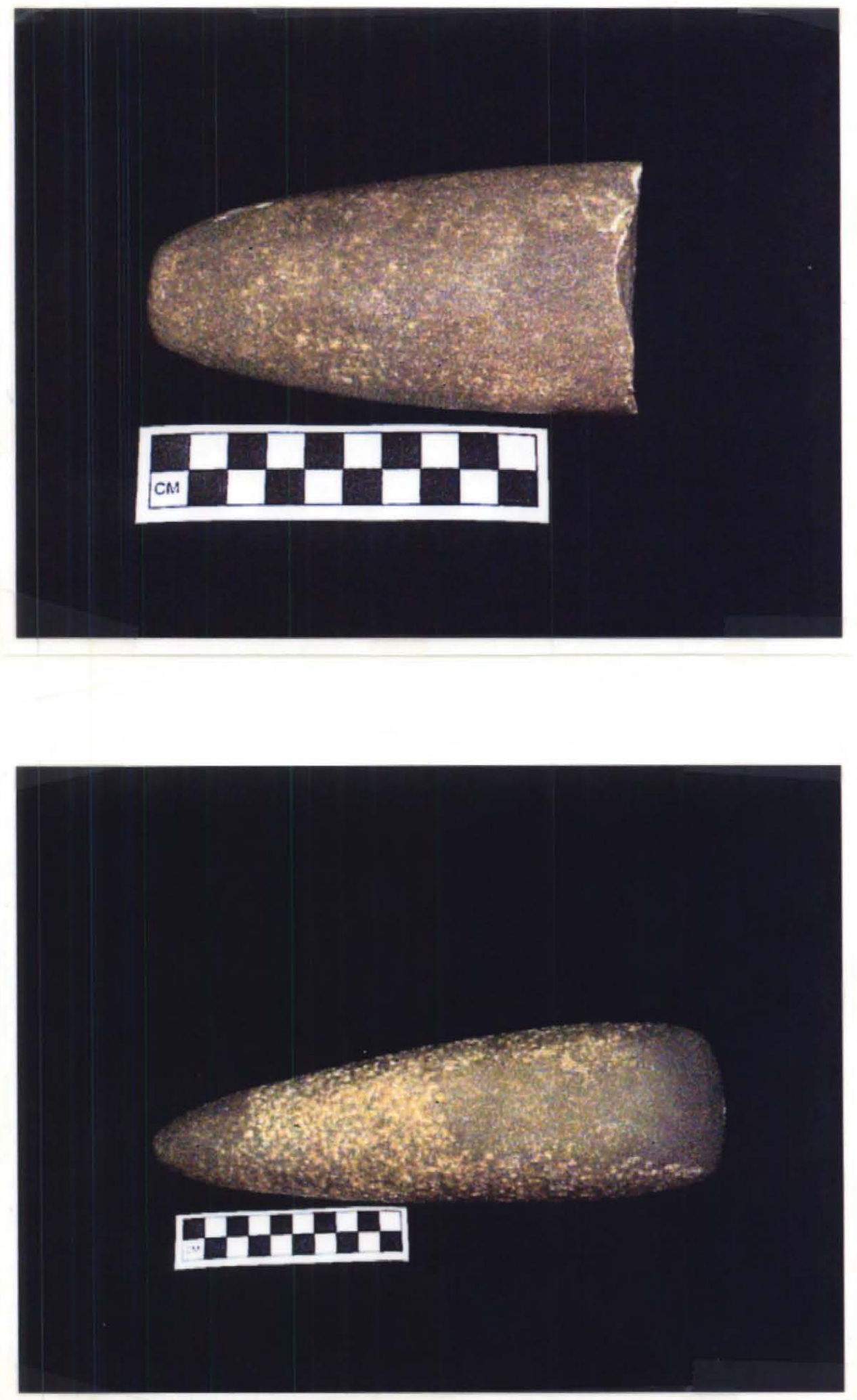

Figure 5. Celts from the Tom Moore site: $a$, top of page; b, bottom of page. 


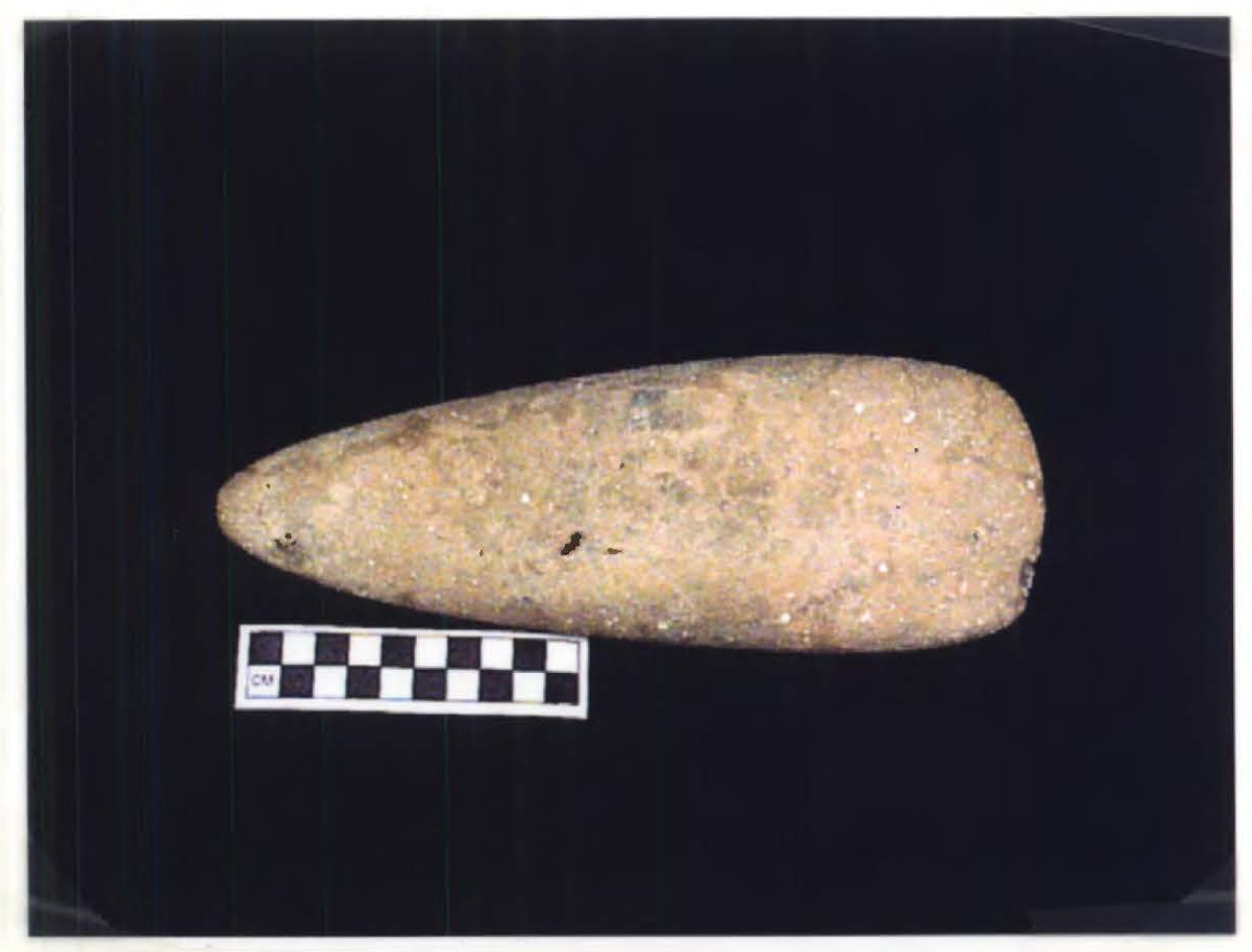

Figure 6. Spatulate celt from the Tom Moore site.

\section{OCR DATES}

While collecting soil samples from the exposed midden area for floatation, three soil samples were taken for OCR dates. Sample \#1 was taken from a $2 \mathrm{~cm}$ thick band at $20 \mathrm{~cm}$ bs and Sample \#2 was taken from a $2 \mathrm{~cm}$ thick band at $30 \mathrm{~cm}$ bs. After receiving the results of these tests another sample (\#3) was taken from the bottom of the midden at $35 \mathrm{~cm}$ bs. While consistent in age, we felt the dates were significantly older than we had expected:

Sample \#1 dated $1502 \pm 45$ B.P., A.D. $403-493$

Sample \#2 dated $1570 \pm 47$ B.P., A.D. $333-427$

Sample \#3 dated $1655 \pm 49$ B.P., A.D. 246-344

Two reasons were given by Douglas Frink (OCR Carbon Dating, Inc., 1997 personal communication) that could have contributed to the older OCR age estimates. One, we pre-screened the sample through 1/4-inch mesh screen. The lack of this coarse fraction may have biased the textural analysis toward a finer-textured soil, and correspondingly have resulted in an older age estimate. The second factor may have been the source of the organic carbon in the sample. If the midden was a mixture of cultural organics and nearby soils (capping, filling, or just eroding into the midden), older organic carbons inherited from the soil's original position may be to blame. It is for this reason that Frink suggested that midden samples be obtained from the lowest portion of the midden to minimize this effect. 


\section{RADIOCARBON DATE}

With a grant from the 'Texas Archeological Society Donor's Fund, we submitted charred maize obtained from the flotation samples (sample 2, 20-30 cm bs) for analysis by Beta Analytic, Inc. for radiocarbon dating (Beta-124359). The conventional radiocarbon age was $360 \pm 60$ B.P. Calibrated results ( 2 sigma, 95\% probability, with a C13/C.12 ratio of -12.9 o/oo) were cal AD 1435 to 1660 . Dr. Tim Pertilualso calibrated the 360 B.P. date, using Stuiver and Reimer (1993), and at 1 sigma, the age ranges are AD 1475-1527 (0.39 relative area under probability distribution $[R A])$ and $A D 1553-1663(0.61 \mathrm{RA})$. At 2 sigma, the age range is AD 1444-1649 (1.00 RA), which means that statistically there is a 95 percent chance that the radiocarbon age of the Tom Moore sample falls between cal AD 1444-1649.

The calibrated radiocarbon age seems late for what has been considered a Middle Caddoan (ca. A.D. 1200-1400) occupation. Either the date is in error or our understanding of what a I ate Caddoan (ca. A.D. 1400-1680) ceramic assemblage would look like, based on very limited data, is misguided. Our limited analyses discussed in this article points to the fact that we need more absolute dates tied to identified phases and components to better identify cultural units in time and space. Distinct decorative elements in dated ceramic assemblages also need to be identified and named before further meaningful archaeological comparisons can be made.

\section{SUMMARY}

The Tom Moore site (4IPN149), although heavily damaged by oil well construction (which could have been avoided if a cultural resources management survey had been required by the Railroad Commission of Texas), still has intact features that can contribute important information on the not well-known prehistory of this area. The remainder of a midden and a possible mound (see Figure 1) are evidence that the site should be protected for future study. Other Middle Caddoan sites in the middle Sabine River basin are apparently characterized by the presence of a single mound covering a circular structure that had been burned, and this may also be the case at the Tom Moore site. The research questions raised conceming subsistence patterns, trade, and ceremonialism need to be addressed in future studies of the site, as well as at contemporaneous Middle Caddoan centers. Certainly the presence of seven large celts of exotic raw materials indicate aspects of trade and exchange between Caddoan groups that have not been noted in most other Fast Texas Middle Caddoan sites. The large size of the celts, their exotic materials, and their special placement in a cache suggests they were placed at the site for a ceremonial rather than utilitarian purpose. Our hope is that by sharing this information on the Tom Moore site, a better understanding and appreciation of the archaeology of Middle Caddoan culture in East Texas will be realized.

\section{REFERENCES CITED}

Arkansas Geological Commission 1998 The Geology of Magnet Cove. Arkansas Geological Commission, I Litle Rock.

Bird, R. M. and C. A. Dobbs

1986 Archaeological Maize from the Vosburg Site (21FA2), Faribault County, Minnesota. The Missouri Archaeologist 47:85-105. 
Blake, L.

1994 Analysis of Rowland Clark Site Corn. Journal of Northeast Texas Archaeology 4:43-49.

Brown, W. L. and E. Anderson

1947 The Northern Flint Corns. Annals of the Missouri Botanical Garden 34:1-28.

Cutler, H. C. and L. W. Blake

1973 Plants from Archaeological Sites East of the Rockies. Missouri Botanical Garden, St. Louis.

Delorit, R. J .

1970 An Illustrated Taxonomy Manual of Weed Seeds. Agronomy Publications, River Falls, Wisconsin.

Early, A. M.

1988 Standridge: Caddoan Settlement in a Mountain Environment. Research Series No. 29. Arkansas Archeological Survey, Fayetteville.

Ford, R. I.

1997 Preliminary Report on the Plant Remains from the George C. Davis Site, Cherokee County, Texas, 1968-1970 Excavations. Bulletin of the Texas Archeological Society 68:104-107.

Fritz, G. J.

1989 Evidence of Plant Use from Copple Mound at the Spiro Site. In Contributions to Spiro Archaeology: Mound Excavations and Regional Perspectives, edited by J. D. Rogers, D. G. Wyckoff, and D. A. Peterson, pp. 65-87. Studies in Oklahoma's Past No. 16. Oklahoma Archeological Survey, Norman.

1992 Archeobotanical Remains of the Five Sites on the Red River, Northeast Texas. Report submitted to the Texas Historical Commission, Austin.

Goldborer, S. E.

1988 Botanical Materials from the Bohannon (34HU61) and Ashland (34HU62) Sites. Report submitted to the Oklahoma Conservation Commission, Norman.

1995 More Macrobotanical Materials from Three Sites along the Red River, Northeast Texas: Ray (41LR135), Fasken (41RR14), and Roitsch (41RR16). Report submitted to the Department of Antiquities Protection, Texas Historical Commission, Austin.

1998 Floral Analysis. Journal of Northeast Texas Archaeology 11:15, 21-22.

Goldborer, S. E. and T. K. Perttula

1999 Macrobotanical Remains from a Northeast Texas I ate Archaic to Middle Caddoan Site: Hurricane Hill (41HP106), Hopkins County. In The Hurricane Hill Site (41HP106): The Archaeology of a Late Archaic/Early Ceramic and Early-Middle Caddoan Settlement in Northeast Texas, edited by T. K. Perttula, pp. 365-382. 2 Vols. Special Publication No. 4. Friends of Northeast Texas Archaeology, Pittsburg and Austin. 
Jones, V. H.

1949 Maize from the Davis Site: Its Nature and Interpretation. In The George C. Davis Site, Cherokee County, Texas, by H. P. Newell and A. D. Krieger, pp. 241-249. Society for American Archaeology, Memoirs 5. Menasha, Wisconsin.

Jones, V. H. and R. L. Fonner

1954 Plant Material from Sites in the Durango and La Plata Areas, Colorado. In Basketmaker II Sites Near Durango, Colorado, by E. H. Morris and R. F. Burgh, pp. 93-115. Publication No. 604. Carnegie Institution of Washington, Washington, D.C.

Martin, A. C. and W. D. Barkley

1961 Seed Identification Manual. University of California Press, Berkeley, California.

Montgomery, F. H.

1977 Seeds and Fruits of Plants of Eastern Canada and Northeastern United States. University of Toronto Press, Toronto.

Perttula, T. K.

2000a Results of the Instrumental Neutron Activation Analysis of Caddo Vessel Sherds from the Tom Moore (41PN149), Bryan Hardy (41SM55), and Redwine (41SM193) Sites in Northeast Texas. Archeological \& Environmental Consultants, Austin.

2000b The Caddoan Ceramics from the Gray's Pasture Site (41HS524), Harrison County, Texas. Journal of Northeast Texas Archaeology 13:1-39.

Stuiver, M. and P. J. Reimer

1993 Extended 14C Data Base and Revised C.ALIB 3.0 14C Age Calibration Program. Radiocarbon 35(1):215-230.

Suhm, D. A. and E. B. Jelks (editors)

1962 Handbook of Texas Archeology: Type Descriptions. Special Publication No.1, Texas Archeological Society, and Bulletin No. 4, Texas Memorial Museum, Austin.

Wagner, G. E.

1986 The Corn and Cultivated Bcans of the Fort Ancient Indians. The Missouri Archaeologist 47:107-136. 